ORIGINAL ARTICLE

\title{
KEYSTONE FLAP FOR RECONSTRUCTION OF SACRAL AND ISCHIAL PRESSURE INJURY
}

\author{
Narottama Tunjung \& Nandita Melati Putri
}

Division of Plastic Surgery, Department of Surgery, Faculty of Medicine Universitas Indonesia, Cipto Mangunkusumo Hospital, Jakarta, Indonesia

\begin{abstract}
Introduction: Reconstruction of sacral and ischial pressure injury offers great challenges due to its high complication and recurrence rate. Providing durable tissue coverage with minimal donor site morbidity is paramount while ensuring fast operative time for the patients who often possess multiple comorbidities. This study aims to present cases of sacral and ischial pressure injury reconstruction using keystone flap.

Method: A retrospective study was performed by reviewing data from fifteen patients with sacral and ischial pressure injury who underwent reconstruction using various type of keystone flap in our center between 2019 and 2020.

Results: The patients' age ranged from 10 to 83 years old (average, 40.5 years old). The average wound dimensions were $9.4 \pm 3.1 \mathrm{~cm} \times 6.5 \pm 2.7 \mathrm{~cm}$ and the mean area of the defects was $52.3 \pm 35.7 \mathrm{~cm} 2$, with the largest defect was 15 $x 12 \mathrm{~cm}(141.3 \mathrm{~cm} 2)$. Mean operative time was $140 \pm 24.5$ minutes with nine wounds were reconstructed using type IV keystone flap $(60 \%)$ and six patients using type IIA (40\%). Postoperative complication occurred on three patients $(20 \%)$. Other patients resulted in uneventful complete healing.

Conclusion: Keystone flap is reliable, simple, has fast technique and minimal donor site morbidity to cover the defects of sacral and ischial pressure injury. Performing thorough debridement, choosing the right type of keystone flap, elevating the flap adequately to allow mobilization, preserving perforator "hotspots", and suturing of the flap without tension are keys to achieve satisfactory results.
\end{abstract}

Keywords: Reconstruction of Sacral; Keystone Flap; Ischial Pressure Injury

\section{ABSTRAK}

Introduksi: Rekonstruksi cedera tekanan sakral dan iskial menawarkan tantangan besar karena tingkat komplikasi dan kekambuhannya yang tinggi. Memberikan cakupan jaringan yang tahan lama dengan morbiditas situs donor minimal adalah yang terpenting sambil memastikan waktu operasi yang cepat untuk pasien yang sering memiliki beberapa penyakit penyerta. Penelitian ini bertujuan untuk mempresentasikan kasus rekonstruksi cedera sakral dan tekanan iskia menggunakan keystone flap.

Metodologi: Sebuah studi retrospektif dilakukan dengan meninjau data dari lima belas pasien dengan cedera tekanan sakral dan iskial yang menjalani rekonstruksi menggunakan berbagai jenis flap batu kunci di pusat kami antara 2019 dan 2020.

Hasil: Usia pasien berkisar antara 10 sampai 83 tahun (rata-rata 40,5 tahun). Dimensi luka rata-rata adalah $9,4 \pm 3,1$ $\mathrm{cm} \times 6,5 \pm 2,7 \mathrm{~cm}$ dan rata-rata luas luka adalah 52,3 $\pm 35,7 \mathrm{~cm} 2$, dengan kerusakan terbesar adalah $15 \times 12 \mathrm{~cm}(141,3$ $\mathrm{cm} 2$ ). Waktu operasi rata-rata adalah $140 \pm 24,5$ menit dengan sembilan luka direkonstruksi menggunakan keystone flap tipe IV $(60 \%)$ dan enam pasien menggunakan tipe IIA $(40 \%)$. Komplikasi pasca operasi terjadi pada tiga pasien $(20 \%)$. Pasien lain menghasilkan penyembuhan total yang lancar.

Kesimpulan: Flap keystone dapat diandalkan, sederhana, memiliki teknik cepat dan morbiditas tempat donor minimal untuk menutupi defek cedera tekanan sakral dan iskia. Melakukan debridemen menyeluruh, memilih jenis penutup keystone yang tepat, meninggikan flap secara memadai untuk memungkinkan mobilisasi, mempertahankan "hotspot" perforator, dan menjahit flap tanpa tegangan adalah kunci untuk mencapai hasil yang memuaskan.

Kata Kunci: Rekonstruksi Sakral; Tutup Keystone; Cedera Tekanan Iskia

Conflicts of Interest Statement:

The author(s) listed in this manuscript declare the absence of any conflict of interest on the subject matter or materials discussed. 


\section{INTRODUCTION}

Pressure injury is a local damage of skin and/or its underlying soft tissue which occurs over a bony prominence or caused by constant pressure from medical or other device.1,2 Pressure injury is also called pressure ulcer, pressure sore, bed sore, and decubitus ulcer. In 2016, the National Pressure Ulcer Advisory Panel (NPUAP) replaced the word "pressure ulcer" to "pressure injury" to elucidate the injury that can also happen in an intact skin.1,3 Pressure injury has become a significant health issue because of its high cost of treatment, debilitating effect on the patients, and the high recurrence rate despite the preventive measures and treatment. ${ }^{4,5,6}$ Pressure injury affects 2.5 million individuals resulting in 60,000 deaths in the US and impacts 700,000 individuals with 29,000 deaths in the UK.5 The cost of pressure injury care in the UK was estimated at between $£ 1.4$ billion and $£ 2.1$ billion annually and 9.1 to 11.6 billion dollars annually in the US. 5,7

While the stage 1 and 2 pressure injury can still be treated non surgically using conventional and modern wound dressing, stage 3 and 4 pressure injury remains in need of surgical treatment. ${ }^{2}$ The surgical treatment consists of debridement of the ulcer and underlying bursa, removal of necrotic bone and bony prominence, removal of dead space, and coverage of soft tissue defect. 8,9 Based on the location, Zhou et $\mathrm{al}^{4}$ reported that from 25,264 patients, most pressure injuries are located in the sacrum, followed by foot and buttocks. Chen et al ${ }^{10}$ stated that sacral pressure injuries pose challenges to reconstruct because patients are usually paraplegic or bedridden, thus healing of the wound could be compromised and the injuries are prone to recurrence.

Many reports have introduced various options to reconstruct pressure injury in the sacrum and ischium. ${ }^{11-24}$ Initially musculocutaneous flap was considered to be the best option since it had robust vascularization and bulkiness of muscle to fill the dead space and provide padding over the bony area of the sacrum and ischium.11-13 Fasciocutaneous flap was later introduced and became widely used to reconstruct sacral pressure injury.10,12,15 The use of locoregional fasciocutaneous flaps such as V-Y flaps, rotational flaps, and limberg flaps have been reported to give less bleeding and operative time, with the same complication and recurrence rate as musculocutaneous flap.10,12,27 Lastly, perforator-based flaps have been gaining popularity for reconstruction of sacral and ischial defects using superior and inferior gluteal artery perforator flaps as well as free flaps. ${ }^{14,17-23}$ This technique, however, requires operator's experience and microsurgical technique of flap dissection to identify the perforator, thus longer operative time is expected. To date, no technique has been proven superior to others. ${ }^{12,15}$

Keystone flap was first introduced by Behan. ${ }^{28}$ A keystone is defined as an apical, curvilinear stone of the Roman arches. The flap resembles 2 or $3 \mathrm{~V}-\mathrm{Y}$ island flaps and allows even distribution of tension along the flap edges. ${ }^{29}$ This fasciocutaneous flap has robust source of vascularization from the perforator underneath and is versatile and can be utilized in various regions of the human body. ${ }^{28,29}$ The flap has evolved into many modifications and is not limited to only cover elliptical shape defect.16,30 This study aims to report the use of keystone flap to reconstruct pressure injury in the sacral and ischial region with varying defect size and provide a simple algorithm on how to choose the type of the keystone flap.

\section{METHOD}

Fourteen patients with stage 3 and 4 pressure injury undergoing reconstruction surgery at our plastic surgery division in 2019 and 2020 were enrolled. Written informed consent was obtained and the study is performed in accordance with the principles of the Declaration of Helsinki. Data were collected retrospectively from the medical records, including patients' age, gender, location and stage of pressure injury, defect size, comorbidities, type of keystone flap, duration of surgery, complication, and follow up data. 


\section{Operative Technique}

The reconstruction of pressure injury was performed in one stage once the patient was stable and tolerable to undergo anesthesia and surgery. Two stages of reconstruction were performed when the patient was not tolerable for long surgery and if the injury and eschar was very extensive which created large dead space under healthy skin. We would perform debridement and application of negative

pressure wound therapy (NPWT) on the first surgery followed by flap coverage on the second surgery. 31

The wound was measured intraoperatively. Circular defects were measured using $\pi \mathrm{r} 2$, while elliptical defects were measured using $\pi \mathrm{r} 1 \mathrm{r} 2$ ( $\mathrm{r}$ is the radius of the defect, $\mathrm{r} 1$ and $\mathrm{r} 2$ are the longest and shortest radius of the ellipse). ${ }^{32}$ We then assessed the laxity of the surrounding tissue to determine the location of the keystone flap design.

Types of keystone flap used were based on the classification by Behan ${ }^{28}$; Type I: The deep fascia is left intact for small defects up to $2 \mathrm{~cm}$; Type IIA: Deep fascia along the outer curvilinear line is divided to facilitate tissue mobilization and defect closure; Type IIB: Deep fascia is divided and a skin graft is used to cover the secondary defects; Type III: Two identical opposing flaps are used to create a double keystone flap; Type IV: The flap is rotated and can be raised up to $50 \%$ of the flap subfascially, with a skin graft that can be applied to cover the secondary defects. Firstly, we identified the location of perforator using a handheld Doppler device.

The perforators were marked, then the keystone flap was drawn by including the perforators in flap, with 1:1 defect-to-flap width ratio for unilateral flap. We then proceed with thorough debridement of the wound. After the debridement, the flap was incised and elevated. When type IV keystone flap was used, we dissected the flap subfascially until $50 \%$ of the flap was elevated while preserving the area of the predicted location of the perforator. The flap could then be advanced to cover the defect or mobilized in an omega-manner of modified keystone type by rotating both limbs of the keystone flap to the middle of the defect. ${ }^{30} \mathrm{~A}$ vacuum drain was inserted and the flap was sutured without tension. We avoided placing the suture line directly above bony prominence to minimize wound breakdown. Postoperatively, we used light dressing on the sutures, and avoided pressure on the flap. The drain was removed between postoperative day 3 to 5. Patients or the caregivers were given instructions on the prevention of recurrence.

\section{RESULTS}

Demographic data, as seen in Table 1, showed ten patients were male $(67 \%)$ and five were female (33\%). The patients' age ranged from 10 to 83 years old (average, 40.5 years old).

Three patients suffered from spinal cord injury, three from ischemic stroke, two patients had chronic kidney disease, two had tumor of the medulla spinalis.

The other patients were presented with cervical ossification, tuberculosis coxitis, spaceoccupying lesion of the spinal canal, cerebral aneurysm, and systemic lupus erythematosus. Two patients were tetraplegic $(13 \%)$, seven patients were paraplegic $(47 \%)$, and six patients were bedridden $(40 \%)$.

Characteristic of the wound showed eleven patients had stage 4 pressure injury $(73 \%)$ while the other four had stage $3(27 \%)$. Thirteen pressure injuries were located at the sacrum $(87 \%)$ and two at the ischium (13\%). The average wound dimensions were $9.4 \pm 3.1 \mathrm{~cm} \times 6.5 \pm 2.7$ $\mathrm{cm}$ and the mean area of the defects was $52.3 \pm$ $35.7 \mathrm{~cm} 2$, with the largest defect was $15 \times 12 \mathrm{~cm}$ $(141.3 \mathrm{~cm} 2)$. The mean operative time was $140 \pm$ 24.5 minutes with nine wounds were reconstructed using type IV keystone flap (60\%) and six patients using type IIA (40\%).

Postoperative complication occurred on three patients $(20 \%)$. One patient had small area of necrosis in the margin of the flap which healed secondarily, one had wound dehiscence at the ischium which had to undergo repair surgery using second keystone flap from the opposite side, and one had recurrence of the pressure injury 3 months after the surgery. There was no partial or total flap loss. During the follow op period, some patients developed hypertrophic scar along the suture line. We then apply silicone sheets for the scars to avoid friction wound on the scar area which could lead to recurrence of pressure injury. 


\section{Case Presentations}

Case 1: A 73-year-old woman with history of multiple ischemic strokes developed pressure injury at the sacrum due to long bed stay. The patient was presented with stage 4 pressure ulcer. The wound's dimension was 16x7 $\mathrm{cm}(87.9 \mathrm{~cm} 2)$ with granulation tissue and eschar on the wound base (Figure 1A). We decided to perform 2 stages of reconstruction because the eschar created extensive subcutaneous pocket and dead space on the superior side. On the first surgery, debridement was done followed by NPWT application. After 2 cycles of NPWT, the patient underwent second surgery of flap coverage. Type IV keystone flap was used from the right superolateral side of the defect (Figure 1B). The flap was elevated at both limbs and mobilized in an omega manner to cover the defect and bony prominence followed by drain insertion and non-tension closure (Figure 1C). At 1-month follow-up the wound was healed with no complication (Figure 1D).

Case 5: A 10-year-old boy was presented with a large unstageable pressure injury at the sacrum. Eschar was covering almost all surface of the wound (Figure 2A). The patient was bedridden and had history of chronic kidney disease undergoing routine hemodialysis and also type I diabetes mellitus. The wound size was $15 \times 12 \mathrm{~cm}(141,3 \mathrm{~cm} 2)$ and was the largest pressure injury in our series. A 1-stage reconstruction was then performed. After the debridement, base of the wound was revealed to be bone, muscle, and fat tissue (Figure 2B). Type IV keystone flap was designed from the left lateral side of the wound, then mobilized to cover the defect and bony prominence using omega modification (Figure 2C). After a 3-months

Table 1. Patient List

\begin{tabular}{|c|c|c|c|c|c|c|c|c|c|c|c|}
\hline Patient & $\begin{array}{l}\text { Age } \\
\text { (years) }\end{array}$ & Gender & $\begin{array}{l}\text { Pressure } \\
\text { Injury } \\
\text { Stage }\end{array}$ & Location & Comorbidity & $\begin{array}{l}\text { Mobilization } \\
\text { Status }\end{array}$ & $\begin{array}{l}\text { Defect } \\
\text { Size } \\
(\mathrm{cm})\end{array}$ & $\begin{array}{l}\text { Area } \\
\left(\mathrm{cm}^{2}\right)\end{array}$ & $\begin{array}{l}\text { Keystone } \\
\text { Flap } \\
\text { Type }\end{array}$ & $\begin{array}{l}\text { Duration } \\
\text { of } \\
\text { surgery } \\
\text { (minutes) }\end{array}$ & Complication \\
\hline 1 & 73 & Female & 4 & Sacrum & $\begin{array}{l}\text { Ischemic } \\
\text { stroke }\end{array}$ & Bedridden & $16 \times 7$ & 87.9 & IV & 150 & None \\
\hline 2 & 54 & Male & 4 & Sacrum & $\begin{array}{l}\text { Cervical } \\
\text { ossification of } \\
\text { the posterior } \\
\text { longitudinal } \\
\text { ligament }\end{array}$ & Tetraplegic & $9 \times 8$ & 56.5 & IV & 160 & None \\
\hline 3 & 83 & Female & 3 & Sacrum & $\begin{array}{l}\text { Ischemic } \\
\text { stroke }\end{array}$ & Bedridden & $6 \times 5$ & 23.5 & IIA & 100 & None \\
\hline 4 & 16 & Male & 3 & Sacrum & $\begin{array}{l}\text { Tuberculosis } \\
\text { coxitis }\end{array}$ & Bedridden & $7 \times 3$ & 16.5 & IIA & 150 & None \\
\hline 5 & 10 & Male & 4 & Sacrum & $\begin{array}{l}\text { Chronic } \\
\text { kidney disease }\end{array}$ & Bedridden & $15 \times 12$ & 141.3 & IV & 180 & None \\
\hline 6 & 11 & Female & 3 & Sacrum & $\begin{array}{l}\text { Tumor of } \\
\text { medulla } \\
\text { spinalis }\end{array}$ & Paraplegic & $8 \times 4$ & 25.1 & IIA & 120 & None \\
\hline 7 & 51 & Male & 4 & Sacrum & $\begin{array}{l}\text { Ischemic } \\
\text { stroke }\end{array}$ & Bedridden & $9 \times 8$ & 56.5 & IV & 160 & $\begin{array}{l}\text { Marginal } \\
\text { necrosis of } \\
\text { the flap }\end{array}$ \\
\hline 8 & 51 & Male & 4 & Sacrum & $\begin{array}{l}\text { Tumor of } \\
\text { medulla } \\
\text { spinalis }\end{array}$ & Tetraplegic & $8 \times 8$ & 50.2 & IV & 120 & None \\
\hline 9 & 55 & Female & 4 & Ischium & $\begin{array}{l}\text { Space- } \\
\text { occupying } \\
\text { lesion of the } \\
\text { spinal canal }\end{array}$ & Paraplegic & $9 \times 6$ & 42.4 & IV & 120 & $\begin{array}{l}\text { Wound } \\
\text { dehiscence }\end{array}$ \\
\hline 10 & 49 & Male & 4 & Sacrum & $\begin{array}{l}\text { Cerebral } \\
\text { aneurysm }\end{array}$ & Paraplegic & $11 \times 6$ & 51.8 & IV & 150 & None \\
\hline 11 & 55 & Male & 4 & Sacrum & $\begin{array}{l}\text { Spinal cord } \\
\text { injury }\end{array}$ & Paraplegic & $5 \times 3$ & 11.7 & IIA & 120 & None \\
\hline 12 & 14 & Male & 4 & Sacrum & $\begin{array}{l}\text { Spinal cord } \\
\text { injury }\end{array}$ & Paraplegic & $12 \times 11$ & 103.6 & IV & 180 & Recurrence \\
\hline 13 & 12 & Male & 3 & Sacrum & $\begin{array}{l}\text { Chronic } \\
\text { kidney disease }\end{array}$ & Bedridden & $10 \times 4$ & 31.4 & IIA & 120 & None \\
\hline 14 & 41 & Male & 4 & Ischium & $\begin{array}{l}\text { Spinal cord } \\
\text { injury }\end{array}$ & Paraplegic & $6 \times 5$ & 23.5 & IIA & 120 & None \\
\hline 15 & 33 & Female & 4 & Sacrum & $\begin{array}{l}\text { Systemic } \\
\text { Lupus } \\
\text { Erythematosus }\end{array}$ & Paraplegic & $10 \times 8$ & 62.8 & IV & 150 & None \\
\hline
\end{tabular}


follow-up, the wound was completely healed. Silicone sheet was applied on the hypertrophic scar (Figure 2D).
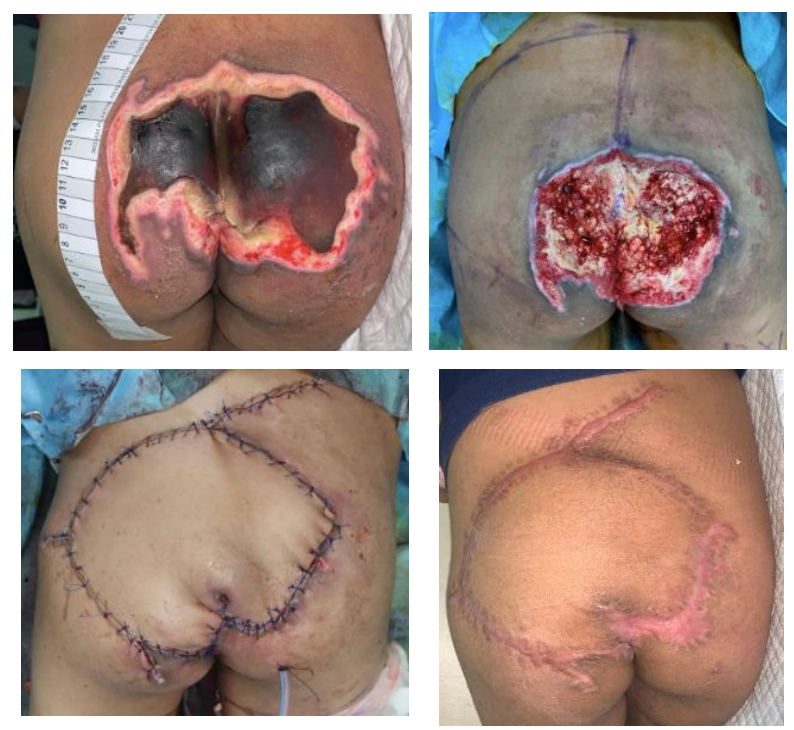

Figure 1. A, 73-year-old woman with stage 4 pressure injury had first surgery of debridement and NPWT application. B, after 2 cycles of NPWT, patient underwent keystone flap type IV reconstruction. C, Postoperative view. D, at 1 month follow-up.

Case 11: A 55-year-old man developed a stage 4 sacral pressure injury resulting from spinal cord injury which had led to tetraplegia.
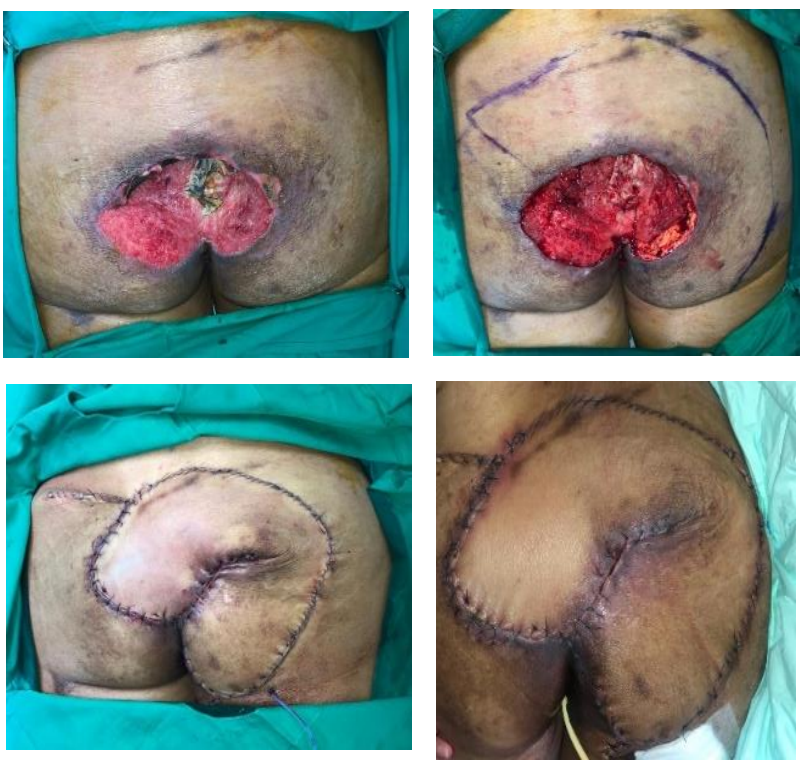

Figure 2. A, 10-year-old boy with a $15 \times 12 \mathrm{~cm}$ pressure injury. B, Patient underwent debridement followed by reconstruction using type IV keystone flap. C, Postoperative view. D, At 3 months followup.
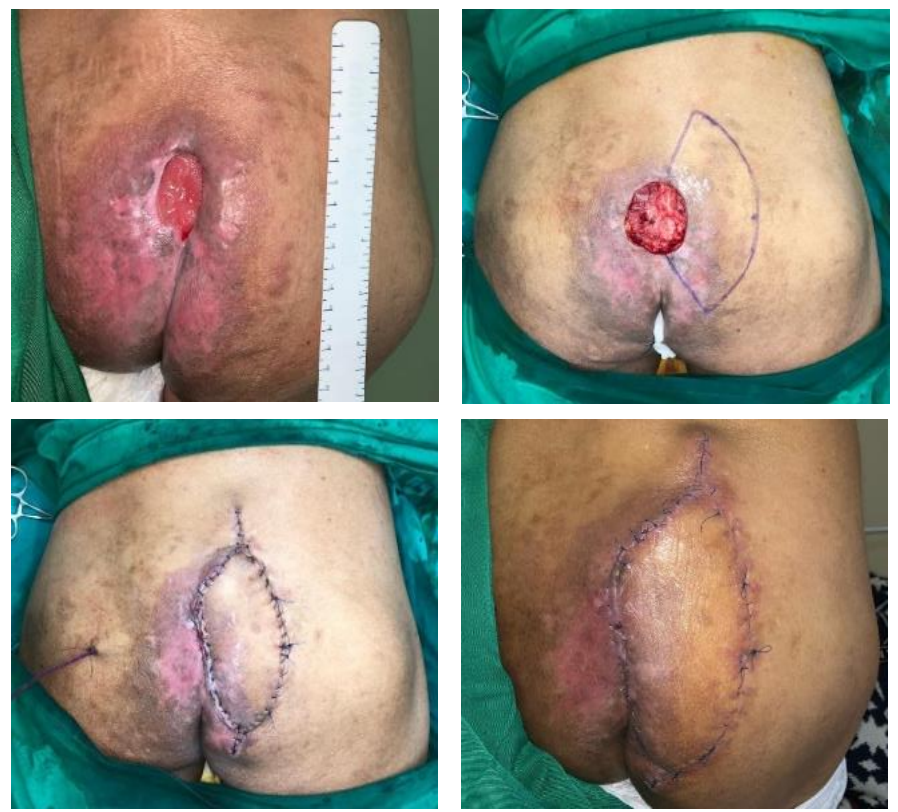

Figure 3. A, A 55-year-old man with stage 4 pressure injury with the size of $5 \times 3 \mathrm{~cm}$. B, Keystone flap type IIA from lateral side was planned. C, the flap was advanced medially. D, At 1 month follow-up.

The wound was $5 \times 3 \mathrm{~cm}(11.7 \mathrm{~cm} 2)$ with muscle on the wound base (Figure $3 \mathrm{~A}$ ). The patient

Copyright by Tundjung, \& Putri (2021)

P-ISSN 2089-6492; E-ISSN 2089-9734 | DOI: 10.14228/jprjournal.v8i1.319

This work is licensed under a Creative Commons License Attribution-Noncommercial No Derivative 4.0 
underwent 1-stage surgery of debridement followed by flap closure. A type IV Keystone flap was utilized from the right lateral side of the defect (Figure 3B). The flap was elevated and advanced medially to cover the defect and bony prominence (Figure 3C). After 1 month, the wound was healed with no complication (Figure 3D).

\section{DISCUSSION}

Plastic and reconstructive surgeons are often encountered and consulted with cases of pressure injury. The reconstruction of pressure injury, especially in the sacral and ischial area, is challenging because the patients are usually bedridden or para/tetraplegic and furthermore, the patients usually have systemic health problems, such as poor nutritional status, cardiopulmonary impairment, kidney disease, diabetes or altered consciousness. 4,8,9 Patients are less likely to be tolerable for surgery and cannot endure long surgery. $8,9,33$ On the other hand, conservative treatment is not always an option because stage 3 and 4 pressure injury without reconstruction could lead to morbidity, low quality of life, sepsis and even mortality. ${ }^{2}$ Thus prompt timing of surgery and fast surgery with the right flap selection is paramount.

Many flaps are available to reconstruct the defect of pressure injury. ${ }^{11-26}$ In the 1970's and 1980 's musculocutaneous flaps were the flap of choice to reconstruct sacral and ischial pressure injury. ${ }^{11,12}$ Muculocutaneous flaps, however, had their disadvantages of sacrificing the function of the muscle, longer duration of operation and more bleeding intraoperatively, and muscles became atrophy over time. ${ }^{12,27}$ Newer studies reported that both musculocutaneous and fasciocutaneous flap provided good and safe pressure injury coverage. ${ }^{12,19,27}$ Koshima et al ${ }^{14}$ introduced perforator-based flap for reconstruction of sacral pressure injury using gluteal artery perforator-based flaps. Since then, perforator-based flap became popular and many reports had shown the versatility of perforator flap. ${ }^{17-23}$ Despite the advantages of perforator flap such as low donor site morbidity and high mobility of the flap, perforator flaps have their limitations as well. Perforator flaps are technically more difficult requiring meticulous dissection of the perforator vessels that can lead to longer operative time and the risk of kinking of the pedicle which can result to total flap loss. ${ }^{10,12,27}$ A systematic review by Sameem et al12 revealed that there was no statistical difference in terms of recurrence or complication rates between musculocutaneous, fasciocutaneous, or perforator-based flaps.

The complication rates of pressure injury reconstruction ranges from 7 to $31 \% .4,12$ This result is consistent with our series with complication rate of $20 \%$. One patient from our series had complication of wound dehiscence requiring repair surgery of ischial pressure injury. Historically, ischial pressure injury had been the most difficult case of pressure injury to reconstruct due to its anatomic location on the inferior gluteal fold which had more motion and prone to pressure increase during mobilization and sitting of the patient.13,19,22 One other patient had recurrence of pressure injury due to the limited healthy skin surrounding the wound. There was scarring around the wound because the patient had history of pressure injury and surgeries performed elsewhere prior to admission.

We used keystone flaps for pressure injury reconstruction because this procedure provided stable coverage using tissue adjacent to the defects, which gave a "like-to-like" effect with none to minimal donor morbidity. ${ }^{28,29}$ Other advantages included the short operative time and the simple technique of designing the flap and elevation of the flap. ${ }^{30}$ The decision to choose which type of keystone flap was based on intraoperative findings including the size of the defects, and the laxity of adjacent skin. Smaller defects $(<40 \mathrm{~cm} 2)$ tend to be closed with type II keystone flap and larger defects $(>40 \mathrm{~cm} 2)$ may be closed with type IV keystone flap. To avoid dehiscence and recurrence, we recommend placing the suture lines of the flap away from bony prominence. By using type IV keystone flap for larger defects, elevation up to $50 \%$ of the flap is important in order to cover the defect and the bony prominence with the flap while still preserving the area of perforator "hotspots". Based on the size of the defect, we propose an algorithm to choose the type of keystone flap by using $40 \mathrm{~cm} 2$ defect area as the cutoff point (Figure 4).

Keystone flap for pressure injury has been reported before by Byun et al.16 The study reported 13 cases of sacral, ischial, and 
trochanteric pressure injury reconstructed using modified keystone flap. The series reported $15.4 \%$ complication rate comparable to our study with $20 \%$ complication rate. Byun et al also reported the mean dimensions of the defect were $7.7 \times 6.5$ $\mathrm{cm}$. Our study, however, reported more patients in the series with 15 patients and larger mean dimensions of the defects with $9.4 \times 6.5 \mathrm{~cm}$. While

Sacral and Ischial Pressure Injury Stage 3 and 4

Debridement of the ulcer and underlying bursa, removal of necrotic bone and bony prominence

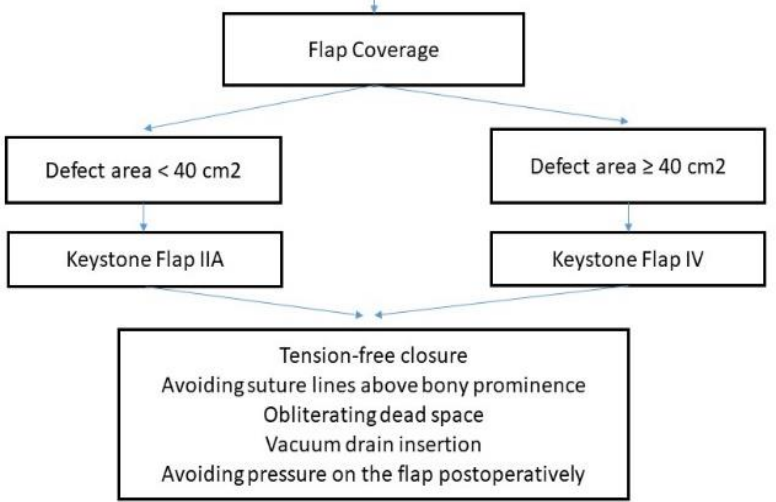

Byun et al utilized one type of modified keystone flap, our study used two types of keystone flap with algorithm proposed on the flap selection.

Figure 4. Algorithm of sacral and ischial pressure injury reconstruction using keystone flap.

In terms of operative time, previous studies reported mean operative time of 216, 165, and 152.9 minutes for perforator-based flap reconstruction of pressure injury. ${ }^{10,21,34}$ Our reports showed faster operative time compared to perforator flap with the mean of 140 minutes. Chen et al10 reported similar result using rotational fasciocutaneous flap with mean operative time of 143.4 minutes. However, Byun et al16 reported faster operative time with modified keystone flap with average of 53.4 minutes. Conclusively, reconstruction using keystone flap yields faster operative time. And in the case of pressure injury where the patients often have multiple comorbidities, prolonged operative time increases the risk of complications. ${ }^{33}$

\section{CONCLUSION}

Overall, the use of keystone flap for reconstruction of pressure injury is satisfactory. The strength of our study includes the utilization of several types of keystone flaps and the proposed algorithm of reconstruction. The limitation of the study is the small sample size of 15 cases and the lack of control group comparing keystone flap with other types of flap.

Providing durable soft tissue coverage and minimizing complications and recurrence are the aim of reconstruction of pressure injury. We used keystone flap as the choice to cover sacral and ischial defects as it offers advantages such as (1) large defects can be closed without tension, (2) the fasciocutaneous flap provides enough padding above bony prominence and has reliable vascularization, (3) the flap can be elevated up to $50 \%$ subfascially and mobilized by advancement and rotation of one or both limbs to cover defects, (5) minimal donor site morbidity, and (6) simple technique and fast operative time.

\section{Correspondence regarding this article should be addressed to:}

Nandita Melati Putri. M.D., Division of Plastic Surgery, Faculty of Medicine Universitas Indonesia, dr. Cipto Mangunkusumo National Hospital, Jakarta, Indonesia. EMail: nalatri@gmail.com

\section{REFERENCES}

1. Edsberg LE, Black JM, Goldberg M, McNichol L, Moore L, Sieggreen M. Revised national pressure ulcer advisory panel pressure injury staging system: revised pressure injury staging system. J Wound Ostomy Continence Nurs. 2016;43(6):585.

2. Lyder $\mathrm{CH}$. Pressure ulcer prevention and management. Jama. 2003;289(2):223-6.

3. Kottner J, Cuddigan J, Carville K, et al. Pressure ulcer/injury classification today: An international perspective. J Tissue Viability. 2020;29(3):197-203.

4. Zhou Q, Yu T, Liu Y, et al. The prevalence and specific characteristics of hospitalised pressure ulcer patients: A multicentre cross-sectional study. J Clin Nurs. 2018;27(3-4):694-704.

5. Padula WV, Pronovost PJ, Makic MB, et al. Value of hospital resources for effective pressure injury prevention: a cost-effectiveness analysis. BMJ Qual Saf. 2019;28(2):132-41.

6. Gillespie BM, Walker RM, Latimer SL, et al. Repositioning for pressure injury prevention in adults. Cochrane Database Syst Rev. 2020(6). 
7. Dealey C, Posnett J, Walker A. The cost of pressure ulcers in the United Kingdom. I Wound Care. 2012;21(6):261-6.

8. Schryvers OI, Stranc MF, Nance PW. Surgical treatment of pressure ulcers: 20-year experience. Arch Phys Med Rehabil. 2000;81(12):1556-62.

9. Sørensen JL, Jørgensen B, Gottrup F. Surgical treatment of pressure ulcers. Am J Surg. 2004;188(1):42-51.

10. Chen YC, Huang EY, Lin PY. Comparison of gluteal perforator flaps and gluteal fasciocutaneous rotation flaps for reconstruction of sacral pressure sores. J Plast Reconstr Aesthet Surg. 2014;67(3):37782.

11. Minami RT, Mills RO, Pardoe R. Gluteus maximus myocutaneous flaps for repair of pressure sores. Plast Reconstr Surg. 1977;60(2):242-9.

12. Sameem M, Au M, Wood T, Farrokhyar F, Mahoney J. A systematic review of complication and recurrence rates of musculocutaneous, fasciocutaneous, and perforator-based flaps for treatment of pressure sores. Plast Reconstr Surg. 2012;130(1):67e-77e.

13. Lee SS, Huang SH, Chen MC, Chang KP, Lai CS, Lin SD. Management of recurrent ischial pressure sore with gracilis muscle flap and VY profunda femoris artery perforator-based flap. J Plast Reconstr Aesthet Surg. 2009;62(10):1339-46.

14. Koshima I, Moriguchi T, Soeda S, Kawata S, Ohta S, Ikeda A. The gluteal perforator-based flap for repair of sacral pressure sores. Plast Reconstr Surg. 1993;91(4):678-83.

15. Borman $\mathrm{H}$, Maral T. The gluteal fasciocutaneous rotation-advancement flap with VY closure in the management of sacral pressure sores. Plast Reconstr Surg. 2002;109(7):2325-9.

16. Byun IH, Kim CW, Park TH. The modified keystone flap for pressure ulcers: a modification of the keystone flap with rotation and advancement. Ann Plast Surg. 2019;82(3):299-303.

17. Coskunfirat OK, Özgentas HE. Gluteal perforator flaps for coverage of pressure sores at various locations. Plast Reconstr Surg. 2004;113(7):2012-7.

18. Lee JT, Hsiao HT, Tung KY, Ou SY. Gluteal perforator flaps for coverage of pressure sores at various locations. Plast Reconstr Surg. 2006;117(7):2507-8.

19. Hallock GG. The propeller flap version of the adductor muscle perforator flap for coverage of ischial or trochanteric pressure sores. Ann Plast Surg. 2006;56(5):540-2.

20. Lemaire V, Boulanger K, Heymans O. Free flaps for pressure sore coverage. Ann Plast Surg. 2008;60(6):631-4.

21. Yang $\mathrm{CH}$, Kuo YR, Jeng SF, Lin PY. An ideal method for pressure sore reconstruction: a freestyle perforator-based flap. Ann Plast Surg. 2011;66(2):179-84.
22. Kim YS, Lew DH, Roh TS, Yoo WM, Lee WJ, Tark KC. Inferior gluteal artery perforator flap: a viable alternative for ischial pressure sores. J Plast Reconstr Aesthet Surg. 2009;62(10):1347-54.

23. Verpaele AM, Blondeel PN, Van Landuyt K, et al. The superior gluteal artery perforator flap: an additional tool in the treatment of sacral pressure sores. Br J Plast Surg. 1999;52(5):385-91.

24. Wettstein R, Tremp M, Baumberger M, Schaefer DJ, Kalbermatten DF. Local flap therapy for the treatment of pressure sore wounds. Int Wound J. 2015;12(5):572-6.

25. Lin CT, Chen SY, Chen SG, Tzeng YS, Chang SC. Parasacral perforator flaps for reconstruction of sacral pressure sores. Ann Plast Surg. 2015;75(1):625.

26. Akan IM, Sungur N, Özdemi R, Klnç H, Sensöz Ö. "Pac Man" flap for closure of pressure sores. Ann Plast Surg. 2001;46(4):421-5.

27. Kuo PJ, Chew KY, Kuo YR, Lin PY. Comparison of outcomes of pressure sore reconstructions among perforator flaps, perforator-based rotation fasciocutaneous flaps, and musculocutaneous flaps. Microsurgery. 2014;34(7):547-53.

28. Behan, FC. The keystone design perforator island flap in reconstructive surgery. ANZ J Surg. 2003;73(3):112-20.

29. Gómez OJ, Barón OI, Peñarredonda ML. Keystone Flap: Overcoming Paradigms. Plast Reconstr Surg Global Open. 2019;7(3).

30. Behan FC, Rozen WM, Lo $\mathrm{CH}$, Findlay M. The omega - $\Omega$ - variant designs (types A and B) of the keystone perforator island flap. ANZ J Surg. 2011;81:650-652.

31. Gupta S, Baharestani M, Baranoski S, et al. Guidelines for managing pressure ulcers with negative pressure wound therapy. Adv Skin Wound Care. 2004;17:1-6.

32. Múslúman AM, Karşidağ S, Sucu DÖ, et al. Clinical outcomes of myelomeningocele defect closure over 10 years. J Clin Neurosci. 2012;19:984-90.

33. Cheng H, Clymer JW, Chen BP, Sadeghirad B, Ferko NC, Cameron CG, Hinoul P. Prolonged operative duration is associated with complications: a systematic review and metaanalysis. J Surg Res. 2018;229:134-44.

34. Chih-Hsun L, Ma H. Use of perforator-based fasciocutaneous flaps for pressure sore reconstruction: Single-perforator-based versus multiple-perforator-based flaps. Aesthet Plast Surg. 2016;40(4):540-8. 